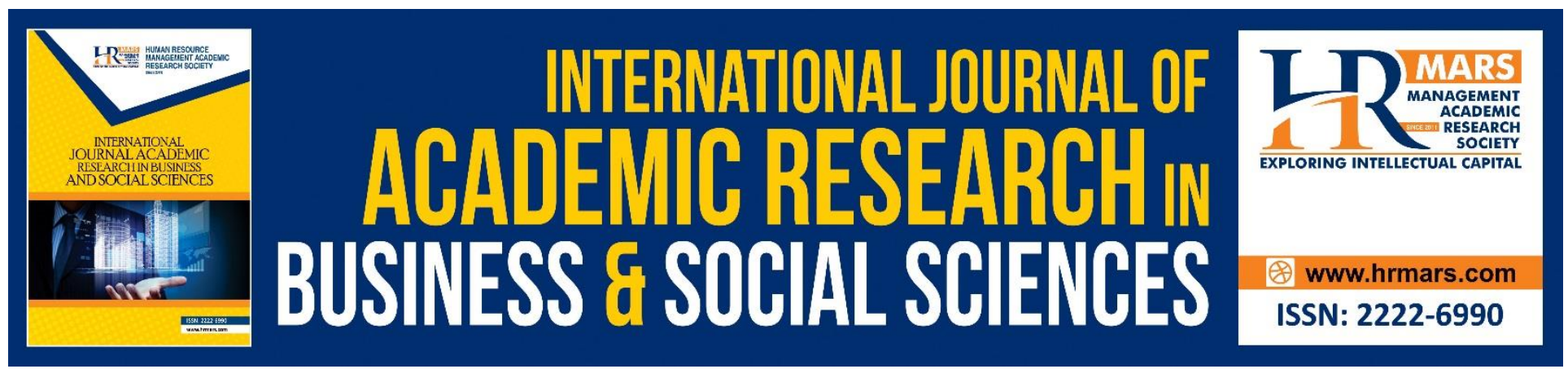

\title{
Application of Entrepreneurial Marketing to the Marketing Mix: Why it Matters to SMEs in Malaysia?
}

\author{
Mohammad Ismail, Fakhrul Anwar Zainol, Wan Norhayate Wan Daud, \\ Norfadzilah Rashid, Asyraf Afthanorhan
}

To Link this Article: http://dx.doi.org/10.6007/IJARBSS/v8-i12/5079

DOI: $10.6007 /$ IJARBSS/v8-i12/5079

Received: 21 Nov 2018, Revised: 23 Dec 2018, Accepted: 28 Dec 2018

Published Online: 30 Dec 2018

In-Text Citation: (Ismail, Zainol, Daud, Rashid, \& Afthanorhan, 2018)

To Cite this Article: Ismail, M., Zainol, F. A., Daud, W. N. W., Rashid, N., \& Afthanorhan, A. (2018). Application of Entrepreneurial Marketing to the Marketing Mix: Why it Matters to SMEs in Malaysia? International Journal of Academic Research in Business and Social Sciences, 8(12), 850-865.

Copyright: (c) 2018 The Author(s)

Published by Human Resource Management Academic Research Society (www.hrmars.com)

This article is published under the Creative Commons Attribution (CC BY 4.0) license. Anyone may reproduce, distribute, translate and create derivative works of this article (for both commercial and non-commercial purposes), subject to full attribution to the original publication and authors. The full terms of this license may be seen

at: http://creativecommons.org/licences/by/4.0/legalcode

\section{Vol. 8, No. 12, 2018, Pg. 850 - 865}

Full Terms \& Conditions of access and use can be found at http://hrmars.com/index.php/pages/detail/publication-ethics 


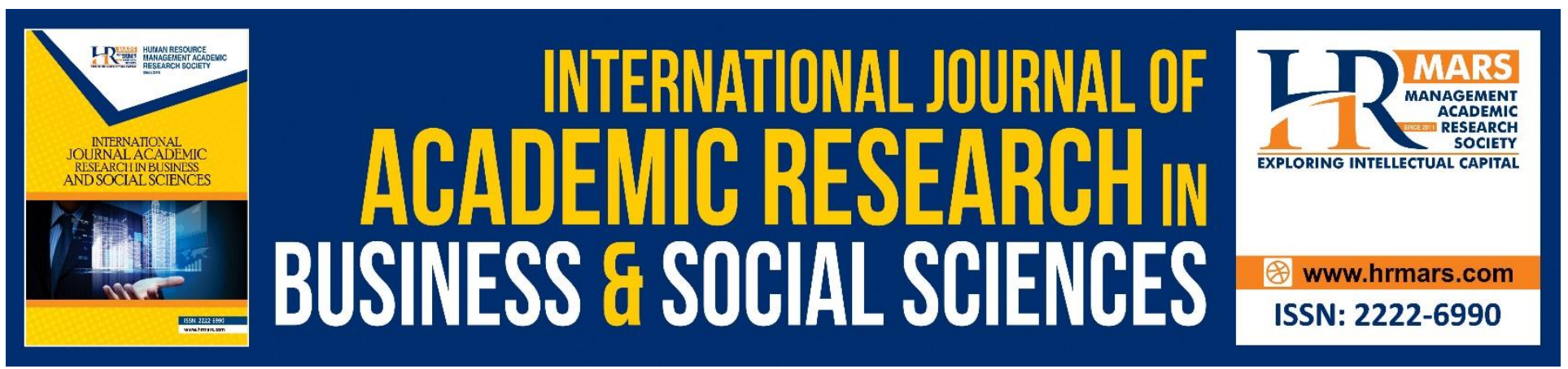

\title{
Application of Entrepreneurial Marketing to the Marketing Mix: Why it Matters to SMEs in Malaysia?
}

\author{
${ }^{1}$ Mohammad Ismail, ${ }^{2}$ Fakhrul Anwar Zainol, ${ }^{3}$ Wan Norhayate Wan \\ Daud, ${ }^{4}$ Norfadzilah Rashid, ${ }^{5}$ Asyraf Afthanorhan \\ ${ }^{1}$ Faculty of Entrepreneurship and Business, Universiti Malaysia Kelantan, 16100, Kota Bharu, \\ Kelantan, Malaysia \\ 2,3,4,5Faculty of Economics and Management Sciences, Universiti Sultan Zainal Abidin, 21300 Kuala \\ Nerus, Terengganu, Malaysia \\ Corresponding Author : mohammad.i@umk.edu.my
}

\begin{abstract}
Small and Medium Enterprise (SME) is an interesting subject to explore on. SME's faced many challenges in operate their business. In the rising turbulent market and with forceful competition and tremendously increasing demanding customers, marketers struggling in predicting consumer demands which changing over the time. Traditional marketing is no longer exceedingly effective and adequate for firms to compete in highly competitive business environment and in making strategic marketing decisions. In dealing with the unpredictable and uncertainty market, firms should be more entrepreneurial in their marketing. Due to that, past studies provides a solution using Entrepreneurial Marketing (EM) for all businesses that needs for competitive advantage in a unpredictable market. Even though a number of research has been conducted on the defining characteristics of EM, but the literature still lack of discussion on practical implementation strategies particularly for those firms interested to apply these practices. This paper presents a review of the literatures on EM, highlights the overview of the EM, and then discussed the application of EM to the model of four P's elements specifically defining characteristics of EM which are opportunity creation, innovation, personal networking, and resource leveraging. Based on the reviewing past literatures, this paper resolves by underlying that applying EM to marketing mix among SMEs or to larger firms should significantly increase the success and competitive advantage of a firm. Future study might explore on other elements of marketing mix that possibly affect the businesses performance.
\end{abstract}

Keywords: Entrepreneurial Marketing (EM), Small and Medium Enterprise (SME), Innovation, Marketing Mix, Implementation. 
INTERNATIONAL JOURNAL OF ACADEMIC RESEARCH IN BUSINESS AND SOCIAL SCIENCES

Vol. 8, No. 12, Dec, 2018, E-ISSN: 2222-6990 @ 2018 HRMARS

\section{INTRODUCTION}

Even though a plethora of research has been conducted pertaining to Small and Medium Sized Enterprise (SME), however very scant research focusing on marketing practices particularly entrepreneurial marketing to marketing mix elements Nowadays firms are facing challenging in operate their business. In the rising turbulent market and with forceful competition and tremendously increasing demanding customers, marketers struggling in predicting consumer demands which changing over the time. Moreover, firms have lack of ability in forecasting and defining their market boundaries (Day and Montgomery, 1999). Traditional marketing is no longer highly effective and adequate for firms to compete in highly competitive business environment and in making strategic marketing decisions. In dealing with the unpredictable and uncertainty market, firms should be more entrepreneurial in their marketing (Read et al., 2009; Santos and Eisen-hardt, 2009). Pertaining to entrepreneurial marketing practices, both real business practice and academic research have documented an evidence of their practices. Past studies reveals that entrepreneurial marketing is practiced by entrepreneurial firms including small firms and new firms. Entrepreneurial marketing is becoming an established field with their own concepts and disciplines (Kangasmaki, 2014). Additionally, marketing and entrepreneurship is investigated and proven have a significant interrelationships and influence each other which will effect on performance. In this turbulent environment, SME's gain great advantages of entrepreneurial marketing for in order for them to compete with the competitors. Due to this, in some cases entrepreneurial marketing is applied in constrained form which leads to the actual definition is not fully sort out (Sole 2013). Besides, Morris et al. (2002) state that "the need for entrepreneurship is greatest when firms face weakening opportunity streams, as well as rapid changes in technology, consumer needs, social values and political roles". It can be said that, if the SMEs or firm have facing of declining trend in sales, regardless due to uninformed combination of the marketing mix or an elusive change in consumer demand, this signify that firm lacks of proper understanding of its market and needs to innovate (Ramos 2016). Therefore, adopting EM theory and practice is deemed more necessary. This study explore how SMEs and firms might employed entrepreneurial marketing to the four P's of marketing mix as a strategic tools for business performance.

The utmost need for EM presents itself in a unpredictable environment, when traditional marketing practice that assume a stable market and generalize market demand are no longer sufficient (Collinson \& Shaw, 2001; Morris et al., 2002). Furthermore, "environmental conditions that are increasingly dynamic, frequently hostile, and mostly complex" create a need for entrepreneurial practices (Pitt et al., 1997). As declared by Morris et al., (2002), implementing EM would be beneficial and conceivably necessary for the majority of businesses operating today (Morris et al., 2002). However, on the other note, EM can be implemented in a different way at each stage of marketing development (Morris et al., 2002).

On the other hand, in determining the business success, marketing scholars and practitioners relying on the same basic elements for success for a long time ago. The firm applied the elements of successful corporate marketing by traditionally boiled down to the well-known of four P's: price, promotion, product, and place (Kotler, 2001). Most of companies typically organize these elements into proven patterns, obviously by following reasonable step-by-step processes. The plans behind the patterns are both highly structured and disciplined (Carson, 1993). As stated by Ramos (2016), it is 
seem appropriate to consider the tradition of the four P's as important even though it would hide the significant differences at the heart of entrepreneurial experience. It has been argues by Gronroos (1994) that the usefulness of the four P's as a general theory is greatly questionable. Still, Martin (2009) claims that many scholars argue and questionable regarding the usefulness of the four P's as a general theory and ineffective for an entrepreneurial firm because of their innovative nature and need for flexibility. Past researchers believe entrepreneurs and today's firms in general need to take an new and non-traditional approach to marketing since the traditional marketing theory is not relevant to meet current needs of the market (Martin, 2009). However, As contended by Morris et al., (2002), all businesses need to stick on traditional marketing mix of four P model and should approach with an entrepreneurial mindset and lens of entrepreneurship. This paper is in line with the study by Morris et al., (2002) and Ramos (2016) and argues that each elements of the four P's marketing mix is vital and still be the basis of EM activities. This paper focus on SMEs as marketing is not only a functional area in large firms but also can apply to SMEs or new ventures as well. Entrepreneurial behaviour has traditionally been linked to the SME sector (Rahim, Wahab \& Saad, 2015).

The aim of this paper is not to produce a robust findings, but significantly make a review of the previous studies for the necessary of EM implementation among SMEs and large firm by linking existing ideas, evidence and discussing a model for implementing EM. This paper is principally in the form of a brief review of the literature with the objective is to answer the question of "How do SMEs can practice entrepreneurial marketing?" The next section elaborates the issues or the problem of the study. We then explain the research method and conclude the paper with its implication in the last section.

\section{THE ISSUES OR PROBLEMS}

Most of the firms facing difficulty to compete in the competitive environment which market are unstable and unpredictable. The market environment that firms operating in The environment in which firms operating in turn into extremely turbulent and fluctuates on a daily basis (Collinson \& Shaw, 2001; Morris et al., 2002). The nature of market as describes by Morris et al. (2002) : An environment consisting of increased risk, decreased ability to forecast, fluid firm and industry boundaries, a managerial mindset that must unlearn traditional management principles, and new structural forms that will not only allow for change, but help to create it. In order to succeed in business, marketers and SMEs must understand these persistent economic changes, able to adapt to them and capable to predict future market demands (Morris et al., 2002). However, this is almost impossible if the firms keeps totally applying the traditional marketing theory. Divergent to traditional marketing practice, this kind of environment has forced businesses to become more innovative in their marketing and management, and better at predicting changes in the market (Collinson \& Shaw, 2001). This scenario create difficulty for SMEs and large corporations in a similar way to discover a competitive advantage in facing today's unpredictable market. In coping with the tremendous growth, changes, complexity and chaos of the market, entrepreneurial marketing offers solution to the demand of the environment (Morris et al., 2002). Despite of proven results, however there are still lack of marketers who have been exposed to this research and taking advantage of it (Collinson \& Shaw, 2001). The companies that employed the principles of EM are seem to greatly 
perfom compared to those who stick to traditional marketing theory only. Therefore, a proper EM practice is essential for firms and SMEs craving to achieve a sustainable competitive advantage. Marketers can no longer rely on traditional generalization of traditional model, and must give more attention to other areas of marketing (Morris et al., 2002).

The objective of this research is to express how the businesses can be more entrepreneurial in their marketing practices rather than further explain how entrepreneurs can market their business. Even though a lot of significant research has been conducted on various aspects of EM, there is still a need for consistency among the research. Lack of a standard definition of EM (Ismail and Zainol, 2018) and practical implications of how to apply EM to any business has urge this research to explore further on this area. This study will help to bridge the gaps in the literature by combining together previous research to make a suggestion that how businesses and SMEs can apply today. This study will offer a model that any firm desiring to act more entrepreneurially which can be implemented utilizing the traditional marketing mix. Past literature documented that there is still lack of practical model for implementing EM theory exists currently. In establishing a basis for the model, the traditional four P's model will be utilized by traditional firms which would serve as the best structure for the resource. Even though many scholars argue the usefulness of the four P's model, Morris et la., (2002) offer solutions by contending that even small firms need to adhere to the traditional marketing mix of the Four P Model and should approach it with an entrepreneurial mind set. This study aligns with and debate that each of the elements of the traditional marketing mix must still be the basis of EM activity. Each of the firm must have a clear understanding of their positioning within the market by making decisions using price, product, promotion, and places of distribution. EM theory appropriate to be applied in any business context, regardless of size or stage of maturity the business. It is necessary to every firm revert to the four P's model of traditional marketing and applied the model based on entrepreneurship perspective.

\section{APPLICATION OF ENTREPRENEURIAL MARKETING TO THE MARKETING MIX}

In order to reduce the gap in the literatures, this section offers further discussion on practical implications as a guide for any firm that desiring to implement EM. This section emphasize on the most appropriate environments to implement EM, illustrates a practical model which firms can employed towards implementing EM. The discussion also provides the solutions by offering the Four P Model by looking each of the four P's through entrepreneurship perspectives by highlighting practical examples of EM for each dimension which can be implemented within any business context. Figure 1 describes the implications of EM on each of the elements of the Four P Model. It should be noted that these examples are not comprehensive, and are meant to instigate marketers and entrepreneurs to expand their thought within each of these decision areas, rather than limit them.

\section{Product}

Product is the essential tools for company to survive in the competitive market environment. The primary goals of all business firm activity is providing valuable and products that really needs by target market. Conventionally, the creation of products and services is determine by market demand. However, many of today's firms and SMEs have lack of focus on demand and produce products based on cost efficient and sales only rather than on innovative value creation (Morris et al., 2002). Most of 
the firms also typically relying on other firms in making decisions and often copycat most successful product offerings by those firms. Thus, the market become overcrowded with duplicate products, often to not meet customer demand and provide an overabundance of substitutable products for customers that affect the firms with little or no competitive advantage. EM firms have to take their environment into account when creating products. The turbulent environment as illustrates by Pitt et al. (1997) have certain implications which are demand rapidly grows which urge companies to update products at a faster pace, resulting in higher rates of product and service innovation (that often leads to higher rates of failure). This also often creates the need for increased product and market specialization (also known as "nichemanship"). This idea of nichemanship requires finding untapped market segments where demand exists and taking advantage of it (Pitt et al., 1997). Most of the entrepreneurs have this kind of characteristic but rarely utilized by larger firms. Innovative value creation started with a product that is needed and desired by a market even though the actual needs or demand is unknown. The firms and SMEs will have large flexibility with the other elements of marketing mix if the demand of that particular product is higher. Prices slightly can be higher, advertising costs can decrease, and mass distribution might occur when firms offer products and service that meet the unknown demand of the market. For example when Apple first introduce iPhone in 2007 by offering customers a product that they never expect they needed. After certain time with the company continual innovation, the demand of iPhone have keep growing which the company almost concur the market that provide significant value to customers. Additionally, due to Apple offers products that are unique, high in value and best in design, customers were willing to pay a steep price. The trend keep continue each time company release new product. Resource leveraging is another important factor that lead to the product creation as proposed by Morris et al. (2002), the "most critical form of leveraging involves the ability to use other people's resources to accomplish the marketer's purpose". This can be done through bartering, borrowing, renting, leasing, sharing, recycling, contracting, and outsourcing (Morris et al., 2002). EM firms excel at finding opportunities to utilize all the resources at their disposal. This is especially critical for SME's who lack adequate financial resources and have smaller networks. Moreover, resource leveraging may also provide significant advantages to larger firms. This can exist by utilizing current products or services as ideas to introduce complementary products, or by realizing that existing plant and equipment are not being utilized to their full capacity, and finding ways to use them to make a profit (Pitt et al., 1997). Furthermore, Pitt et al. (1997) state that using one product line to generate sales of another line illustrates a more entrepreneurial perspective. Recently, with the changes in consumer trend, today's consumers have high expectations for products and services. Today's customer demand for better design (which includes both functionality and appearance) which they consider more important compare to previous generation (Markelz, n.d.). Today's consumers expect aesthetic products that are easy to use. The company like Apple succeeds off of this understanding and at the same time the customer also expect excellent customer service, online shopping, free shipping, etc. However, in order to make the product entrepreneurial, it is not just requires meet customer demand only but beyond than that, marketers have to figure out innovative ways to exceed market expectation in order to deliver the great customer experience. All this thing only can be accomplished by creating customer needs, not just only have the ability to predict the market and by possessing an extreme understanding of the market, (Morris et al., 2002). 
INTERNATIONAL JOURNAL OF ACADEMIC RESEARCH IN BUSINESS AND SOCIAL SCIENCES Vol. 8, No. 12, Dec, 2018, E-ISSN: 2222-6990 @ 2018 HRMARS

Table 1. The implication and example of entrepreneurial product strategy

\begin{tabular}{|l|l|l|}
\hline No & Implications of an Entrepreneurial Product Strategy & $\begin{array}{l}\text { Examples of Entrepreneurial } \\
\text { Products }\end{array}$ \\
\hline 1 & $\begin{array}{l}\text { Adopting a keen awareness of market needs \& ability } \\
\text { to predict future demand }\end{array}$ & $\begin{array}{l}\text { Dominating unique market } \\
\text { through nichemanship need to } \\
\text { control pricing }\end{array}$ \\
\hline 2 & $\begin{array}{l}\text { Finding opportunities to create demand for unknown } \\
\text { needs }\end{array}$ & $\begin{array}{l}\text { Developing products that } \\
\text { generate sales of another } \\
\text { product line }\end{array}$ \\
\hline 3 & $\begin{array}{l}\text { Focusing on the customer experience, not just product } \\
\text { and services }\end{array}$ & $\begin{array}{l}\text { Designing products that fulfil } \\
\text { an unknown need to create } \\
\text { demand }\end{array}$ \\
\hline 4 & $\begin{array}{l}\text { Leveraging resources to increase productivity, } \\
\text { efficiency, and market knowledge }\end{array}$ & $\begin{array}{l}\text { Focusing on product/service } \\
\text { aesthetic, not just the } \\
\text { functionality }\end{array}$ \\
\hline 5 & $\begin{array}{l}\text { Continually updating and changing products } \\
\text { products }\end{array}$ & $\begin{array}{l}\text { Focusing on customer } \\
\text { experience of product/service, } \\
\text { not just the sale }\end{array}$ \\
\hline $50 u r c e$ Adapted from Ramos (2016)
\end{tabular}

Source: Adapted from Ramos (2016)

Due to rapid changes in today's market, it is necessary for marketers to continual product evolution. All in all, the implications of an entrepreneurial product strategy consist of several elements such as a thorough understanding of one's market demands, a constant search for new product and service opportunities, leveraging available resource to increase utilization, and using an innovative mindset which can help the company for inventing the new products or rethinking about existing products

\section{Price}

Price is considered as a heart of the marketing mix since price is the only element of marketing mix that can generate revenue. According to Levy (2011), price is one of the marketing mix elements that commonly overlooked. Besides, Pitt et al., (1997) state that, traditional marketing normally assumes the function of pricing based on two practical functions which are to make a profit and to maintain a competitive positioning among substitute products. Based on Corporate Traditional Marketing (CTM), firms usually utilizing pricing strategies which are cost-based (prices are determined based on the cost of creating and delivering the product or service) and reactive (firms adjust their pricing based on the pricing strategies of their competitors). Most of the firm become more creative in their pricing strategy due to increasing competition and homogenous products and services offered by the 
firms (Levy, 2011). In contrast, based on EM "pricing should be a core part, and a reflection of corporate and/or business unit strategy" (Pitt et al., 1997). Due to increasing of turbulent market, there is a need for pricing decisions to focus on the external environment (Pitt et al., 1997). In applying EM, the role of pricing is not just focusing on covering costs and making a profit. Many scholars would claim that a firm's success is "increasingly dependent on their ability to engage in pricing that is market-based, risk-assumptive, proactive, and flexible," regardless of the industry or size. As declared by Pitt et al., (1997), marketing managers are "forced to abandon conservative, risk aversive pricing approaches when faced with rapidly maturing products, demands from customer groups for unique product/service packages, and aggressive competitor forays into their markets". In a unpredictable market, firms no longer can rely on cost-based pricing strategy due to it not give firms the flexibility particularly when customer expectations change over the time, when new market opportunities arise, and when competitors introduce new strategies and making market-based pricing a necessity. The meaning of a flexible pricing strategy means firms need an innovation in adjusting each of the price variables (Pitt et al., 1997). The complex environment permit the firms to "act independently (or undetected) on price within a given niche" (Pitt et al., 1997). This has been applied by Apple's remarkable technology paired with a unified integration between the iPhone, iPad and Macbook creates a package that does not offers by others which help them to sell products at a higher price point and been accepted by the market. The important step to entrepreneurial pricing is proactivity which most firms react to the market or their competitors, rather than setting a new standard. The ultimate goal of price should be to proactively restrain competitors from entering the market (Pitt et al., 1997). As provides by Pitt et al., (1997), a few examples of entrepreneurial pricing consist of innovative, proactive, and flexible: bundling and/or unbundling one's product offerings for pricing purposes, charging price differentials to different market segments, varying price based on time of consumption, various time payment schemes, and creative discount structures. Moreover, the way individual businesses implement entrepreneurial pricing will regularly look different. SME's, have more flexibility when it comes to pricing (Pitt et al., 1997). For small businesses owners, especially those within a supportive community, consumers are often willing to spend a greater amount on a product or service in order to support a local business. Conversely, pricing strategy becomes extremely significant for larger firms since the environment becomes more competitive and unpredictable. It also vital to note that each of the elements of the marketing mix do not function independently of one another, but each of the element directly affect each other. Price is possibly the appropriate example which is the higher the cost of production, promotion, and distribution, the higher the price must be to cover up the cost. On the other hand, the more differentiated and specialized a product or service, the more a firm can control the price of the product. This is proven that the nichemanship is so effective in today's market which can creates high customer value by fulfilling a specific demand in the market, allowing for higher control over pricing strategy and structure (Levy, 2011). 
INTERNATIONAL JOURNAL OF ACADEMIC RESEARCH IN BUSINESS AND SOCIAL SCIENCES Vol. 8, No. 12, Dec, 2018, E-ISSN: 2222-6990 @ 2018 HRMARS

Table 2 The Implications of entrepreneurial Pricing Strategy

\begin{tabular}{|c|c|c|}
\hline No & Implications of an Entrepreneurial Pricing Strategy & $\begin{array}{l}\text { Examples of Entrepreneurial } \\
\text { Pricing }\end{array}$ \\
\hline 1 & $\begin{array}{l}\text { Abandoning cost-based pricing for market-based } \\
\text { pricing }\end{array}$ & $\begin{array}{l}\text { Bundling or unbundling } \\
\text { products to take advantage of } \\
\text { price }\end{array}$ \\
\hline 2 & Implementing a creative price structure & $\begin{array}{l}\text { Varying prices between } \\
\text { market segments }\end{array}$ \\
\hline 3 & Implementing a creative price structure & $\begin{array}{lll}\begin{array}{l}\text { Various time payment } \\
\text { schemes }\end{array} & \\
\end{array}$ \\
\hline 4 & $\begin{array}{l}\text { Using price as a strategy to discourage competitor } \\
\text { market entry }\end{array}$ & Creative discount structures \\
\hline 5 & $\begin{array}{l}\text { Willingness to take on a higher-risk pricing strategy for } \\
\text { possible greater return }\end{array}$ & $\begin{array}{l}\text { Emphasizing nichemanship to } \\
\text { create new pricing standard }\end{array}$ \\
\hline 6 & Utilizing proactive rather than reactive pricing & \\
\hline
\end{tabular}

Source: Adapted from Ramos (2016)

Overall, even though many marketers presume that price is an objective element of the marketing mix, in an unstable market calls managers to develop a creative price strategy. This denotes that firms abandon cost-based strategies for market-based strategies, utilize proactive rather than reactive pricing, and allow higher risk approaches to pricing. SMEs specifically need to be more innovative in designing their pricing strategies.

\section{Promotion}

Generally, product cannot reach the target market without promotion. Target customers lack of knowledge about the existence of the product in the market without promotion. Traditional marketing especially larger corporations puts an over-emphasis on promotion (Morris et al., 2002). With the new digital marketing methods through the Internet and social media over the past decade has offered new opportunities for advertising, and also presents new challenges. Even though its proven significant but very rare businesses have an integrated marketing plan to merge traditional and digital advertising strategies (Villar, 2014). As consumers are blasted with a plethora of advertising messages daily and being exposed to the messages everywhere, this has resulted traditional advertising method become irrelevant (Lee, 2012). Many firms and SMEs crash into promotional aspect only without take into account the importance of creating products with high perceived value and developing innovative pricing strategies. This overemphasis resulted many traditional firms fail, promoting products and services which does not in line with market demands because lack of understanding (Morris et. al, 2002). In order to ensure the effectiveness of utilizing an entrepreneurial promotional strategy, the other elements of marketing mix which are product, pricing, and promotional strategies are need to use the same principles of innovation, opportunity creation, and resource leveraging. Previously, most of the marketing activities focus on transaction, 
INTERNATIONAL JOURNAL OF ACADEMIC RESEARCH IN BUSINESS AND SOCIAL SCIENCES Vol. 8, No. 12, Dec, 2018, E-ISSN: 2222-6990 @ 2018 HRMARS

but as the environment change particularly in an over-crowded market, a paradigm shift of focus which emphasis on the relationship between businesses and their customers (Morris et al., 2002). In applying EM, firms need to apply same mindset to their promotional marketing strategy. Now days, consumers cannot simply being influence by common marketing strategies such as billboards, TV commercials, mailers, etc. All those strategies are appropriate for creating awareness but lack of engagement and personal touch with the customers (Lee, 2012). Firms can obtain lot of advantages applying EM principles to promotion. As describes by Lee (2012), Harvard Business Review suggested several ways to approach promotional marketing innovatively, starting with focusing on building relationships and advertising that focus on is also the important element (Ramos, 2016). Recently, social media play significant impact in building the relationship between firms and their customers. Social media has proven as powerful tool in gaining and maintaining interaction with customers (Kirtis \& Karahan, 2011; Kaplan \& Haenlein, 2012; Goldman \& Gibbs Howard, 2013). As declared by Kirtis and Karahan (2011) low costs to operate social media, personal and constant presence has resulted attractive marketing opportunity for EM firms (2011). On the other hand, effective promotional marketing needs proper planning and research which should begins with an understanding the customer base (Villar, 2014). Entrepreneurial promotional marketing concentrate on creating great perceived value for customers and building relationships between businesses and their customers (Morris et. al., 2002). Eventually, Entrepreneurial Marketing apparently act as a basis forms or marketing, such as guerilla marketing (Morris et. al, 2002). This strategy is employed by many SMEs as an option for low cost to reach a high volume of customers.

Table 3 The Implications of entrepreneurial Promotion Strategy

\begin{tabular}{|l|l|l|}
\hline No & Implications of an Entrepreneurial Promotion Strategy & $\begin{array}{l}\text { Examples of Entrepreneurial } \\
\text { Promotion }\end{array}$ \\
\hline 1 & Thorough understanding of customers' buying activities & $\begin{array}{l}\text { Effectively utilizing relationships } \\
\text { promote brand, whether } \\
\text { personal or through customer } \\
\text { influencers }\end{array}$ \\
\hline 2 & $\begin{array}{l}\text { Integrated marketing strategy that includes digital } \\
\text { marketing }\end{array}$ & $\begin{array}{l}\text { Using social media to drive two- } \\
\text { way communication }\end{array}$ \\
\hline 3 & $\begin{array}{l}\text { Possessing a thorough understanding of target marketing in } \\
\text { order to deliver an effect message that will appeal the their }\end{array}$ & $\begin{array}{l}\text { Guerilla marketing and other } \\
\text { high-reach, low-cost methods }\end{array}$ \\
\hline 4 & $\begin{array}{l}\text { Finding opportunities to build community thorough social } \\
\text { media and other means }\end{array}$ & $\begin{array}{l}\text { Using cause-related marketing to } \\
\text { connect to the emotional side of } \\
\text { the sales experience }\end{array}$ \\
\hline 5 & Utilizing social movements to showcase heart of brand & Utilizing innovative, grassroots marketing techniques \\
\hline
\end{tabular}

Source: Adapted from Ramos (2016) 
Promotional strategy usually is the critical part of the marketing mix but most of the managers often cannot promote effectively. Basically, firms have a strong capacity in building the awareness but most of them having difficulty in term of connection aspect of promotional marketing. Entrepreneurial Promotion Strategy needs an individualized approach to advertising. An effective entrepreneurial marketing and innovative promotional strategy need to be applied by SMEs in helping them survive in the competitive environment.

\section{Place (Distribution)}

The ultimate goal of distribution channel is to ensure how the end user can receive the product or services. If something go wrong in distribution channel will affect the firms performance. As stated by Sulaiman and Masri (2017), it is important to ensure the functioning of product distribution channels to deliver products to target consumers. Firms can devoted all their effort in designing the superior product, create the best price structure and building a strong promotional strategy but if the product cannot reach the target market, it will lead to failure of the businesses. In traditional marketing, distribution involves supplying products, delivering products, and making them available for sale (Sales and Distribution Channels, 2006). The effective distribution will be evaluate based on how effective it can help to realize sales activity. Those activity consist of: grasping the customer's attention, delivering the value of the product/service and building trust between the buyer and seller, making transactions more convenience, and providing solutions for the customer to receive the product or service (Sales and Distribution Channels, 2006). Previously, the traditional distribution channels were highly standardized and limited to traditional retailers in which demand is already established. However, with the introduction of the Internet had built up a new world of distribution possibilities for retailers. The company like Amazon is one of the businesses example that break the brick and mortar retail standard and redefined distribution in general; selling every imaginable product category online and taking over significant market share from traditional retailers (Sales and Distribution Channels, 2006).

In designing distribution strategies, EM firms must exploit this great opportunity of technology changes. Distribution strategies is different depending on nature of businesses whether business sell directly to retailers, online, to other businesses through wholesale, or to third party service. In order for the firms and SMEs to adopt EM strategies, they needs first to understand the buying habits of their target market and utilizing that information in creating opportunities to increase sales. 
INTERNATIONAL JOURNAL OF ACADEMIC RESEARCH IN BUSINESS AND SOCIAL SCIENCES

Vol. 8, No. 12, Dec, 2018, E-ISSN: 2222-6990 @ 2018 HRMARS

Table 4 The Implications of entrepreneurial Distribution Strategy

\begin{tabular}{|l|l|l|}
\hline No & Implications of an Entrepreneurial DistributionStrategy & $\begin{array}{l}\text { Examples of Entrepreneurial } \\
\text { Distribution }\end{array}$ \\
\hline 1 & $\begin{array}{l}\text { Possessing a thorough understanding of consumer } \\
\text { purchase behaviour to provide product/service where } \\
\text { demand exist }\end{array}$ & $\begin{array}{l}\text { Utilizing networks to } \\
\text { distribute products through } \\
\text { partnerships with larger } \\
\text { retailers }\end{array}$ \\
\hline 2 & $\begin{array}{l}\text { Practicing efficient resource utilization throughout } \\
\text { entire distribution process }\end{array}$ & $\begin{array}{l}\text { Varying distribution strategies } \\
\text { based on segment }\end{array}$ \\
\hline 3 & $\begin{array}{l}\text { Utilizing opportunities to form partnerships with other } \\
\text { distributors }\end{array}$ & $\begin{array}{l}\text { Creative distribution/shipping } \\
\text { methods to reduce expenses } \\
\text { channels that offer the } \\
\text { greatest reach or are currently } \\
\text { untapped bycompetitors }\end{array}$ \\
\hline 4 & $\begin{array}{l}\text { Possessing awareness of areas of greater customer } \\
\text { demand }\end{array}$ & $\begin{array}{l}\text { Utilizing an innovative and proactive mindset rather } \\
\text { than reactive to find new channels of distribution } \\
\text { before competitors }\end{array}$ \\
\hline 6 & $\begin{array}{l}\text { Continually looking for opportunities to ease barriers } \\
\text { to purchasing products }\end{array}$ & \\
\hline $50 u r c e$ & Adapted from Ramos (2016) \\
\hline 5
\end{tabular}

Source: Adapted from Ramos (2016)

Distribution channel might involve the process of transport the product to the target customers which involve logistic matters among the four P's, therefore entrepreneurial distribution strategy needs the great innovation and creativity to differentiate it from traditional method. This denotes that firms needs an understanding of their best potential distribution channels, regularly alert on customer demand, and utilize the networks effectively and efficiently in developing retail partnerships. Figure 1 below describes how the utilization of entrepreneurial marketing to the four P's of marketing mix that in turn give impact to the firms and SMEs. 


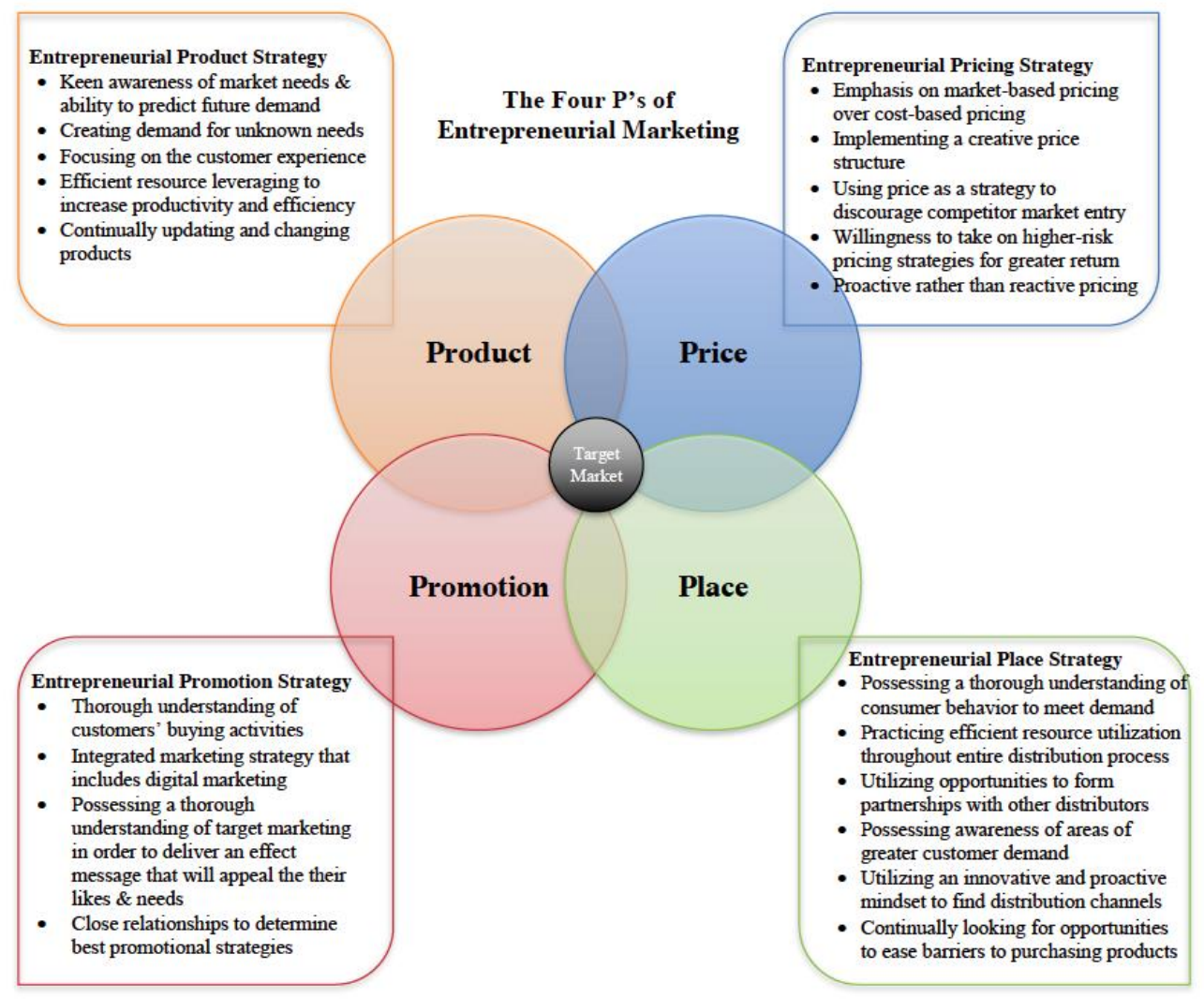

Figure 1: The Impact of EM Management on the Marketing Mix

Source: Adapted from Ramos (2016)

\section{METHODOLOGY}

As the goal of this research is not to introduce new findings, but rather to make a review for the necessity of EM implementation by relating existing ideas, and discussing existing model for implementing EM, this study is primarily in the form of a literature review. No parties were studied or interviewed during the research process. The primary sources used to search for existing literature on EM were from a few established databases, including Google Scholars, Ebscohost and. The majority of sources used were peer reviewed-scholarly articles. In order to get a thorough understanding of the background of Marketing, Entrepreneurship and Entrepreneurial Marketing, each of these terms were searched to find the most relevant literature. Key word searches also included "Entrepreneurial Marketing" and "Marketing Mix." The relevance of each article was weighed by the relevancy of the issues discussed, how recently the article was published, the influence of the journal based on its indexed, number of citations, and its relation to the topic of research.

\section{CONCLUSION AND IMPLICATIONS}

With an increasingly turbulent market, marketers are finding difficulty predicting consumer demands, and academics have found that traditional marketing theory is no longer highly effective in making 
educated marketing decisions. With the growth in the EM research over the past several decades, researchers have found these practices to be effective not only for SME's but also for larger firms. Even though a number of research has been conducted on the defining characteristics of EM, the literature still lack of discussion on practical implementation strategies that firms interested to apply these practices. The model adopted offered in this research applies the defining characteristics of EM which is a search for opportunity, innovative value creation, personal networking and resource leveraging with regard to each element of the marketing mix. This model requires an innovative management strategy and an extreme external focus on the market. Implications for practice involve constantly looking for new opportunities, while maintaining a flexible and market-focused mindset. By applying these principles regardless either SME's or to larger firms, would significantly increase the success of a firm, increase competition among firms, and fulfil the needs of the market via nichemanship. Further qualitative research could include inquiries into specific practices in each of the Four P's to affirm the validity of the adopted model presented in this paper. The study then can compare the results of the findings to the characteristics of EM and the model presented in this paper and highlights any discrepancies. Finally, further study could involve an in-depth analysis of Entrepreneurship Marketing with regards to other elements of marketing mix rather than just focusing on Four P's of marketing mix which might offer better results in performance of SMEs.

\section{Acknowledgement}

We express much appreciation to the Ministry of Education (MOHE) and Universiti Malaysia Kelantan, Malaysia for their part in this important review research.

\section{REFRENCES}

Abdul Rahim, H., Ab. Wahab. K., \& Saad, A. (2015). The shift from traditional marketing to Entrepreneurial Marketing Practices: A Lierature Review. Business and Management Studies.1(2), 134-139

Carson, D. (1993). A Philosophy for Marketing Education in Small Firms. Journal Of Marketing Management, 9(2), 189-204.

Collinson, E., \& Shaw, E. (2001). Entrepreneurial marketing - a historical perspective on development and practice. Management Decision, 39, 761-766. No doi.

Day, G. and D. Montgomery (1999). Charting new directions for marketing. The Journal of Marketing, 3-13.

Goldman, P. and Gibbs Howard, S. (2013). To Tweet or not to tweet: What businesses can learn from social movements. Rotman Magazine, Spring 2013, 46-51.

Gronroos, C., (1994). From marketing mix to relationship marketing - towards a paradigm shift in marketing, Management Decision, 32(4),4-20

Ismail, M., \& Zainol, F.A. (2018). A review on the evolution and definition of entrepreneurial marketing. International Journal of Academic Research in Business and Social Sciences, $8(5), 649-663$.

Kangasmaki, M. (2014) Planning and Implementation of Entrepreneurial Marketing processes in SMEs. Dissertation (Master). 
INTERNATIONAL JOURNAL OF ACADEMIC RESEARCH IN BUSINESS AND SOCIAL SCIENCES

Vol. 8, No. 12, Dec, 2018, E-ISSN: 2222-6990 @ 2018 HRMARS

Kaplan, A. M. \& Haenlein, M. (2012). The Britney Spears universe: Social media and viral marketing at its best. Business Horizons. 55, 27-31.

Kirtiş, A. K., Karahan, F. (2011). To be or not to be in social media arena as the most cost-efficient marketing strategy after the global recession. Procedia-Social and Behavioral Sciences, 24, 260-268.

Kotler., P., \& Armstrong., G. (2001). Principles of Marketing, 9th ed. (Upper Saddle River,

NJ: Prentice Hall, 193-197

Kraus, S., Harms, R. \& Fink, M. (2010). Entrepreneurial Marketing: Moving beyond Marketing in New Ventures. International Journal of Entrepreneurship and Innovation Management, 11(1), 19-34.

Lee, B. (2012). Marketing Is Dead. Harvard Business Review. Retrieved from https://hbr.org/2012/08/marketing-is-dead

Levy, K. (2011, November 30). Price; Marketing's Most Delicate "P" Retrieved from http://www.forbes.com/sites/keithlevy/2011/11/30/price-marketings-mostdelicate p/\#23febb9a1b97

Markelz, M. (n.d.). User-Centric Brands Win Favor With Millennials. Retrieved from https://www.ama.org/publications/eNewsletters/MarketingInsightsNewsletter/Pages/mille nnials-favor-user-centric-brands.aspx

Martin, D. M. (2009) The entrepreneurial marketing mix, Qualitative Market Research: An International Journal, 12, 391 - 403.

Morris, M. H., Schindehutte, M., \& LaForge, R. W. (2002). Entrepreneurial marketing: A construct for integrating emerging entrepreneurship and marketing perspectives. Journal of Marketing Theory and Practice, 10(4), 1-19. Retrieved from https://seu.idm.oclc.org/login?url=http://search.proquest.com.seu.idm.oclc.org/docview/2 12182937 ?accountid $=43912$

Pitt, L. F., Berthon, P. R., \& Morris, M. H. (1997). Entrepreneurial pricing: The cinderella of marketing strategy. Management Decision, 35(5), 344-350.

Ramos, S.V. (2016). Entrepreneurial Marketing: A Historical Exploration and Implications for Practice. Selected Honors Theses. Paper 46.

Read, S., N. Dew, S. Sarasvathy, M. Song, and R. Wiltbank (2009). Marketing Under Uncertainty: The Logic of an Effectual Approach. Journal of Marketing 73 (3), 1-18.

Sales and Distribution Channels. (2006). Retrieved from http://entrepreneurship.org/ /media/Entrepreneurship/Files/Entrepreneurship/Entreprene

u $\quad$ rship/Sales and Distribution Strategies and Channels.pdf

Santos, F. and K. Eisenhardt (2009). Constructing Markets and Shaping Boundaries: Entrepreneurial Power in Nascent Fields. The Academy of Management Journal 52 (4), 643-671.

Sole, M. (2013) Entrepreneurial marketing: conceptual exploration and link to performance. Journal of Research in Marketing and Entrepreneurship. 15. 1. 23-38.

Sulaiman, Y., \& Masri., M. (2017). The impact of marketing mix on consumer preference towards supplement product. Journal of Advance Research in Social Sciences, 7(1), 33-41. 
INTERNATIONAL JOURNAL OF ACADEMIC RESEARCH IN BUSINESS AND SOCIAL SCIENCES Vol. 8, No. 12, Dec, 2018, E-ISSN: 2222-6990 @ 2018 HRMARS

Villar, J. J. (2014). Merging Digital and Traditional Lead Generation Strategies. Journal Of Financial Planning, 27(11), 22-23. 